\title{
Freeze-thaw cycles have minimal effect on the mineralisation of low molecular weight, dissolved organic carbon in Arctic soils
}

\author{
A. Foster ${ }^{1}$ D. L. Jones ${ }^{1} \cdot$ E. J. Cooper ${ }^{2} \cdot$ P. Roberts ${ }^{1}$
}

Received: 20 April 2015/Revised: 23 January 2016/Accepted: 26 February 2016/Published online: 11 March 2016

(C) The Author(s) 2016. This article is published with open access at Springerlink.com

\begin{abstract}
Warmer winters in Arctic regions may melt insulating snow cover and subject soils to more freezethaw cycles. The effect of freeze-thaw cycles on the microbial use of low molecular weight, dissolved organic carbon (LMW-DOC) is poorly understood. In this study, soils from the Arctic heath tundra, Arctic meadow tundra and a temperate grassland were frozen to $-7.5^{\circ} \mathrm{C}$ and thawed once and three times. Subsequently, the mineralisation of 3 LMW-DOC substrates types (sugars, amino acids and peptides) was measured over an 8-day period and compared to controls which had not been frozen. This allowed the comparison of freeze-thaw effects between Arctic and temperate soil and between different substrates. The results showed that freeze-thaw cycles had no significant effect on $\mathrm{C}$ mineralisation in the Arctic tundra soils. In contrast, for the same intensity freeze-thaw cycles, a significant effect on $\mathrm{C}$ mineralisation was observed for all substrate types in the temperate soil although the response was substrate specific. Peptide and amino acid mineralisation were similarly affected by FT, whilst glucose had a different response. Further work is required to fully understand microbial use of LMW-DOC after freeze-thaw, yet these results suggest that relatively short freeze-thaw cycles have little effect on microbial use of LMW-DOC in Arctic tundra soils after thaw.
\end{abstract}

\section{P. Roberts}

p.roberts@bangor.ac.uk

1 School of the Environment, Natural Resources and Geography, Bangor University, Bangor, UK

2 Department of Arctic and Marine Biology, Faculty of Biosciences, Fisheries and Economics, UiT The Arctic University of Norway, 9037 Troms $\varnothing$, Norway
Keywords Below-ground respiration - Carbon cycling Climate change $\cdot$ Freezing temperature $\cdot$ Polar soils

\section{Introduction}

A conservative estimate of global soil organic $\mathrm{C}$ stocks is about $2200 \mathrm{Pg}$ in the top $1 \mathrm{~m}$ (Batjes 1996). There is approximately $472 \mathrm{Pg}$ SOC in the top $1 \mathrm{~m}$ of Arctic regions, which is $>21 \%$ of the above global estimate, making the Arctic an important store of SOC (Hugelius et al. 2014). However, there is uncertainty as to the fate of this SOC with climate change predicted to increase Arctic temperatures and, potentially, soil temperatures and $\mathrm{C}$ degradation. There is also uncertainty as to how increases in air temperature will affect winter soil temperatures. Warmer winter temperatures could increase the occurrence of above $0{ }^{\circ} \mathrm{C}$ soil temperatures and melt insulating snow cover, causing freeze-thaw cycles (FTC), where soils freeze and then thaw or vice versa, when air temperatures drop (Henry 2008; Førland et al. 2011). Alternatively, projected increased precipitation could lead to increased snow depth, providing insulation from fluctuating air temperatures and thus warmer, more stable soil temperatures (Førland et al. 2011; Semenchuk et al. 2013). Results from the Canadian Arctic suggest that the occurrence of FTC may increase at high latitudes as global temperatures increase (Henry 2008). FTC have been shown to affect C dynamics in soil with changes to $\mathrm{CO}_{2}$ emissions, DOC concentrations and microbial biomass being observed (Schimel and Clein 1996; Larsen et al. 2002; Grogan et al. 2004; Matzner and Borken 2008). However, inconsistencies exist in these observations, and increased mechanistic understanding of FTC effects would be beneficial (Matzner and Borken 2008). It is important to identify what effect 
FTC may have on $\mathrm{C}$ turnover and allocation within Arctic soils to better understand potential feedbacks of climate change (Anisimov et al. 2007).

Most soil organic C (SOC) is not immediately available to heterotrophic microorganisms as it is composed of high MW, insoluble polymers that require extracellular enzymatic cleavage to low molecular weight (LMW) compounds prior to use (van Hees et al. 2005; Farrar et al. 2012). LMW dissolved organic carbon (DOC) is generally considered to contain molecules $<1000 \mathrm{Da}$, and much of it $(<650 \mathrm{Da})$ can be taken up directly into the cell via specific transporters (Payne and Smith 1994). It is produced by the breakdown of larger organic matter, directly from root and microbial exudates and from desorption of molecules precipitated/bound on particle surfaces. LMW-DOC is an important substrate for soil micro-organisms (van Hees et al. 2005). It is comprised of a large variety of compounds including, but not limited to, amino acids, organic acids, amino sugars, mono and polysaccharides, peptides, lipids, sterols and phenolics (Kalbitz et al. 2003; van Hees et al. 2005). Certain compounds within this complex mixture are turned over rapidly by the microbial community and can be major contributors to total soil respiration (Boddy et al. 2007; Fujii et al. 2010).

Freeze-thaw cycles (FTC) have been shown to sometimes, though not always, increase the concentrations of DOC and to affect microbial activity and community structure (Stres et al. 2010; Yu et al. 2011). FTC can produce LMW-DOC by causing damage and fatality to roots and microbes and by breaking up soil aggregates (Tierney et al. 2001; Herrmann and Witter 2002; Henry 2007). Some studies have shown that FTC can induce severe microbial mortality, resulting in large changes in microbial community size and structure (Skogland et al. 1988; Stres et al. 2010; Wilson and Walker 2010). However, these laboratory studies used freezing temperatures and frequencies more extreme than those naturally experienced in soil. Where Arctic or alpine tundra soils which are adapted to lower temperatures were used, less change to the microbial community structure was observed (Männistö et al. 2009; Stres et al. 2010). However, changes in fungal growth relative to bacteria have been shown to occur after FTC, though both increases and decreases have been observed, whilst fungi have been shown to be more active at stable freezing temperatures than bacteria (Feng et al. 2007; McMahon et al. 2009; Haei et al. 2011). Repeated, mild FTC decreased microbial biomass carbon in sub-Arctic tundra (Larsen et al. 2002; Grogan et al. 2004).

How the microbes use the released DOC has not been studied in detail. Once produced, LMW compounds such as amino acids, peptides and glucose are rapidly consumed (within minutes) by the microbial community and the $\mathrm{C}$ used for both cell maintenance and growth (Hill et al. 2008,
2012). The subsequent partitioning of the LMW C inside the cell has previously been operationally split into two functional pools: one $\mathrm{C}$ pool is used immediately for respiration and the other $\mathrm{C}$ pool for biosynthesis before eventually being respired (Boddy et al. 2008; Glanville et al. 2012). A third pool has occasionally been assigned to represent more recalcitrant products of biosynthesis (Farrar et al. 2012). The proportion assigned to each pool depends on the substrate and can provide useful insights into $\mathrm{C}$ use efficiency and microbe responses to abiotic and biotic stresses (van Hees et al. 2005). Whether microbial use of LMW-DOC is affected by FTC is less well known, but Lipson and Monson (1998) showed no change in the respiration of glycine or glutamate after a FTC in alpine tundra. Degens et al. (2001) found less variability in the mineralisation of different LMW-DOC compounds in temperate soils after $1 \mathrm{FTC}$ to $-30{ }^{\circ} \mathrm{C}$, but the variability returned to normal after 4FTC. Further investigation will help illuminate the precise mechanisms that occur during FTC and provide more information on the fate of released DOC.

The aim of this study was to identify how the mineralisation of LMW-DOC is affected by FTC in both an Arctic and temperate soil and to see whether repeated FTC have more or less effect than a single cycle. A number of studies have shown the most damaging effects of FT to be observed within the first couple of cycles (Skogland et al. 1988; Yu et al. 2011) so some difference between 1 and 3FTC may be observed. We tested the hypotheses that FTC will cause a shift in microbial $\mathrm{C}$ use efficiency and mineralisation rate, that this change will be compound specific, that FTC will have a greater impact on the mineralisation of LMW-DOC in the temperate soil than the Arctic soil and that 3FTC will have less effect than 1FTC. To achieve this, soils from the Arctic tundra and a temperate grassland were subjected to FTC. Subsequently, ${ }^{14} \mathrm{C}$-labelled LMW-DOC compounds were added and their evolution as ${ }^{14} \mathrm{CO}_{2}$ was monitored.

\section{Methods}

\section{Soils}

Individual replicate soil samples $(n=4)$ were collected from three sites. Two contrasting Arctic tundra vegetation sites in Svalbard were chosen: Arctic heath soil (Dryas octopetala and bare soil dominated) was sampled from Kolhaugen, Ny Ålesund (78 $\left.55.224^{\prime} \mathrm{N} ; 11^{\circ} 52.439^{\prime} \mathrm{E}\right)$ and Arctic meadow soil (Salix polaris and lichen dominated) was sampled from Westbyelva, Ny Alesund $\left(78^{\circ} 55.4^{\prime} \mathrm{N}\right.$; $\left.11^{\circ} 54.4^{\prime} \mathrm{E}\right)$. Soil was also sampled from a temperate grassland (Lolium perenne and Trifolium repens dominated) in 
Abergwyngregyn, UK $\left(53^{\circ} 14.20^{\prime} \mathrm{N} ; 04^{\circ} 01.03^{\prime} \mathrm{W}\right)$. The average winter temperature (1981-2009) in Ny-Ålesund, Svalbard, was $-12^{\circ} \mathrm{C}$ (Førland et al. 2011), whereas the average winter temperature for the same period at the temperate site was $3.4^{\circ} \mathrm{C}$ (UK Met Office Statistics). Arctic soils are frozen from October to June and can experience variable snow cover from bare soil to $>1 \mathrm{~m}$ (Norwegian Meteorological Institute Statistics). The heath site is more exposed than the meadow site and experiences colder soil temperatures (Fig. 1). The temperate soil seldom freezes or experiences snow cover (UK Met Office Statistics). The heath site is approximately $50 \mathrm{~m}$ a.s.1, whilst Westbyelva and Abergwyngregyn are $25 \mathrm{~m}$ a.s.1.

Both Arctic soils are cryosols, the Arctic heath soil is a sandy mineral soil beneath a very shallow/absent organic layer, whilst the Arctic meadow tundra soil has an organic layer up to $10 \mathrm{~cm}$ thick overlying a gravel-rich mineral layer. The temperate soil is a grazed grassland, Eutric Cambisol soil type. Samples were taken randomly over an area of half a hectare. Soils were sampled at a depth of $5 \mathrm{~cm}$ over a diameter of $10 \mathrm{~cm}$. The variable thickness of the organic layer at the meadow site meant that the soil sampled at $5 \mathrm{~cm}$ was either mineral (meadow mineral) or organic (meadow organic), and replicates $(n=4)$ of both soil types at that depth were collected. The organic layer at the heath site generally did not reach $5 \mathrm{~cm}$ so only the mineral soil (heath mineral) was sampled. The overlying vegetation of the precise area sampled was similar for that of the entire site, save in the case of the heath mineral soil which was taken from mostly bare soil areas as the $D$. octopetala cover was patchy. Arctic soils were sampled in July 2012, whilst the temperate soil was sampled in January 2013. After sampling, soils were stored in oxygen permeable bags, stored at $5^{\circ} \mathrm{C}$ and transported to Bangor University and subsequently stored at $5{ }^{\circ} \mathrm{C}$.

\section{Chemical analysis}

Soil extractions (1:2.5 v/v soil/deionised water) were performed to assess soil nutrient status. Soil microbial biomass $\mathrm{C}$ was measured using the soil fumigation-extraction method of Vance et al. (1997). Briefly $10 \mathrm{~g}$ of soil was fumigated with chloroform for $24 \mathrm{~h}$. Then, DOC was extracted from fumigated and non-fumigated soil by shaking in deionised water, and the difference in $\mathrm{C}$ content was assumed to represent the microbial biomass C. Fumigated and non-fumigated deionised water extracts were analysed for total organic C (TOC) and total dissolved $\mathrm{N}$ (TDN) on a TOC-V-TN analyser (Shimadzu Corp., Kyoto, Japan). Inorganic $\mathrm{N}\left(\mathrm{NO}_{3}{ }^{-}\right.$and $\left.\mathrm{NH}_{4}{ }^{+}\right)$was measured using the methods outlined by Miranda et al. (2001) and Mulvaney (1996) DON was estimated by subtraction of $\mathrm{NO}_{3}{ }^{-}$ and $\mathrm{NH}_{4}{ }^{+}$from the TDN value. Soil $\mathrm{pH}$ was measured in 1:2.5 (v/v soil/water) slurries, whilst moisture content was measured gravimetrically after heating to $105{ }^{\circ} \mathrm{C}$ overnight. Total Soil $\mathrm{C}$ and $\mathrm{N}$ were measured using a Carlo Erba NA 1500 Elemental Analyzer (Thermo Fisher Scientific, Milan, Italy). Soil characteristics are given in Table 1.

\section{Freeze-thaw cycles}

Treatment consisted of either 1 FTC or repeated (3) FTC and controls (i.e. no FTC) for each FTC treatment. Coarse roots and stones $>2 \mathrm{~mm}$ were removed by sieving the sampled soils prior to treatment. Fresh soil (2 g) was taken from each replicate for each of the 4 treatments. Soils were frozen to $-7.5{ }^{\circ} \mathrm{C}$ at a rate of $1{ }^{\circ} \mathrm{C} \mathrm{h}^{-1}$, and this temperature was maintained for 2 days. Soils were then thawed at a rate of $1{ }^{\circ} \mathrm{C} \mathrm{h}^{-1}$ to $5{ }^{\circ} \mathrm{C}$. This freezing temperature is representative of winter soil temperatures at the Arctic sites (minimum of -7.5 and $-9.4{ }^{\circ} \mathrm{C}$ at $1 \mathrm{~cm}$ depth for the meadow and heath site, respectively, during winter 2012-2013) and is also seen in other sites in Svalbard (Morgner et al. 2010; Semenchuk et al. 2013). Similarly, rapid changes in soil freezing temperature have also been observed (Semenchuk et al. 2013). In the repeated FTC, this temperature was maintained for 2 days after which the freeze-thaw cycle was repeated a further 2 times. The mineralisation of the LMW $\mathrm{C}$ substrates in the soils was tested $12 \mathrm{~h}$ after the air temperature had returned to $5^{\circ} \mathrm{C}$
Fig. 1 Average daily soil temperatures in the winter of 2012-2013 measured by temperature data loggers at $1 \mathrm{~cm}$ depth at the Arctic sites

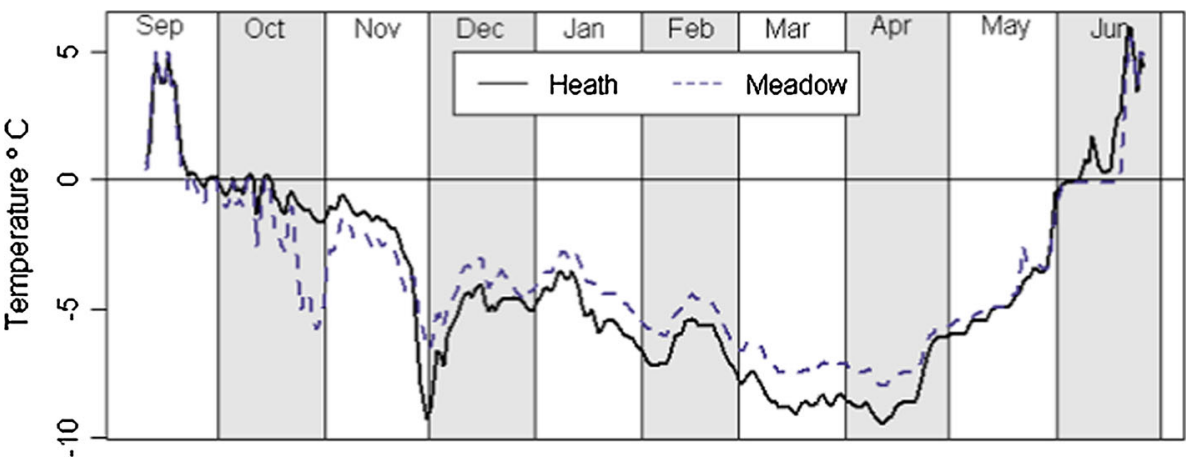




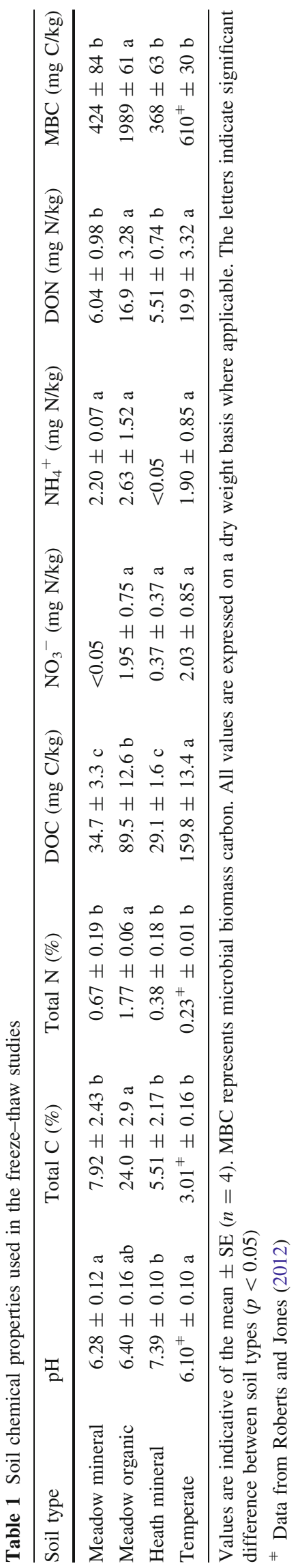

after either 1 or 3 FTC. Controls soils were maintained at $5{ }^{\circ} \mathrm{C}$.

\section{DON and DOC mineralisation}

The mineralisation rates of LMW DON and DOC compounds were determined for three substrates: the oligopeptide trialanine $(231 \mathrm{Da})$, an amino acid mixture (equimolar mix of L-isomeric alanine, arginine, aspartic acid, glutamic acid, glycine, histidine, isoleucine, leucine, lysine, phenylalanine, proline, serine, threonine, tyrosine and valine, 75-174 Da) and the sugar, glucose (180 Da). For the ${ }^{14} \mathrm{C}$-labelled glucose and amino acid substrates, $200 \mu \mathrm{l}$ of a $100 \mu \mathrm{M}$ solution $\left(1.2 \mathrm{kBq} \mathrm{ml}^{-1}\right)$ was added to the soil surface. For trialanine, $200 \mu \mathrm{l}$ of a $10 \mu \mathrm{M}$ solution $\left(1.4 \mathrm{kBq} \mathrm{ml}^{-1}\right)$ was added to the soil. The soils were incubated at $5{ }^{\circ} \mathrm{C}$ in sealed $50-\mathrm{ml}$ polypropylene tubes in which an alkali trap $(1 \mathrm{ml}$ of $1 \mathrm{M} \mathrm{NaOH})$ was placed to trap the ${ }^{14} \mathrm{CO}_{2}$ produced. Traps were exchanged after 0.5 , $1,2,4,7,21,30,48,72$ or 96 and $168 \mathrm{~h}$. The ${ }^{14} \mathrm{C}$ content of the $\mathrm{NaOH}$ traps was determined using a Wallac 1409 scintillation counter (PerkinElmer Corp., Waltham, MA) and Hi-Safe OptiPhase 3 scintillation cocktail (PerkinElmer Corp.). From this, the percentage of the added ${ }^{14} \mathrm{C}$ remaining in the soil at each sampling time was calculated by subtracting the $\%{ }^{14} \mathrm{C}$ emitted from 100 .

A double first-order decay model was fitted to the resulting data

$Y=\left(a_{1} \mathrm{e}^{(-k 1 t)}\right)+\left(a_{2} \mathrm{e}^{(-k 2 t)}\right)$

where $Y$ is the ${ }^{14} \mathrm{C}$ remaining in the soil, $a_{1}$ and $a_{2}$ are the relative sizes of the quickly and more slowly turned over fractions of substrate, respectively, $k_{1}$ and $k_{2}$ are their associated rate constants and $t$ is time. As alanine, trialanine and glucose in the temperate soil have been shown to be taken up in minutes by soil micro-organisms, but only slow, limited sorption observed in sterile soils (Hill et al. 2008, 2012), the quickly turned over substrate fraction can be considered to represent substrate immediately respired by micro-organisms, whilst the more slowly turned over substrate fraction characterises the substrate that is incorporated into biomass which may then be subsequently respired. It should be noted that ${ }^{14} \mathrm{C}$ incorporation into the biomass was not physically measured and only the temperate grassland soil has been tested for mineral adsorption. Thus, the capacity of the Arctic soils for the LMWDOC sorption maybe greater in which case some of the $a_{2}$ pool could include substrate bound to soil particles. This model has been shown to be a good fit for the mineralisation over 2 weeks of the LMW DOC substrates used in this study and in a number of environments including temperate grasslands and Arctic tundra (Boddy et al. 2007; 
Farrell et al. 2011; Glanville et al. 2012). The double firstorder exponential decay model was found to generally be a significantly better fit than the single first-order exponential decay model using the extraF.nls function in the FlexParamCurve library of $\mathrm{R}$ to perform an $\mathrm{F}$ test (Oswald et al. 2012). The parameters of the double first-order exponential decay model were also used to assess carbon use efficiency for the temperate soil as described by Farrell et al. (2011), assuming $a_{2}$ represents $\mathrm{C}$ used for biosynthesis.

\section{Statistics}

Significant effects of soil type, substrate type, FT treatment and time (the duration of the experiment which was shorter for 1FTC than for 3FTC), plus significant interactions, were assessed using a weighted least-squares full-factorial ANOVA for each parameter derived from the fitted model. Within each soil type, a weighted least-squares full-factorial ANOVA was applied to examine the effect of substrate type, FT treatment and time for that soil. Tukey's post hoc test was used to identify where significant differences occurred between FT treatment and associated controls within each soil and substrate type. Differences in mineralisation parameters between soil types for the first control were examined using weighted least-squares one-way ANOVA and Tukey's post hoc test. Only the first controls were used as these would be more representative of initial soil values. Significant differences between soil chemical characteristics were identified using one-way ANOVA and Tukey's post hoc test. All statistics were performed in SPSS version 20 (SPSS Inc., Chicago, IL). Differences were considered significant where $p<0.05$.

\section{Results}

\section{Soil chemical properties}

The heath mineral soil had a significantly higher $(p<0.001$; Table 1) $\mathrm{pH}$ than the other soils. No other significant differences were observed in the chemical characteristics of the two Arctic mineral soils $(p>0.05$; Table 1), whilst the meadow organic soil had a significantly higher soil $\mathrm{C}(p<0.001$; Table 1$), \mathrm{N}(p<0.001$; Table 1), and microbial biomass C (MBC; $p=0.004$, $p=0.008$ and $p<0.001$ for the meadow mineral, heath mineral and temperate soils, respectively; Table 1) than the other soils. The temperate soil had the greatest DOC concentrations $(p<0.001$ for all soils; Table 1$)$. The DON concentrations were significantly greater in the temperate and meadow organic soils than in the meadow mineral and heath mineral soils $(p=0.007$ and $p=0.006$ for the temperate soil, $p=0.034$ and $p=0.026$ for the meadow organic soil; Table 1). The $\mathrm{pH}$, soil $\mathrm{C}$ and soil $\mathrm{N}$ of the temperate soil were not measured in this analysis; values from the same soil type, measured by Roberts and Jones (2012) have been provided for reference.

\section{Soil mineralisation parameters}

In all soils and for all substrates, a biphasic pattern of mineralisation was observed. A double-exponential decay model was found to fit well to this experimental mineralisation data $\left(r^{2}=0.971\right.$ to $\left.>0.999\right)$ (Figs. $\left.2,3,4,5\right)$. A significant effect of both soil and substrate was observed for all mineralisation parameters ( $p<0.001$ for all). There were significant differences in the modelled mineralisation parameters for the first cycle controls between soil types (Figs. 6, 7; Tables 2, 3, 4). The first rate constant $\left(k_{1}\right)$ describing the rate of trialanine turnover was significantly different between the soil types, with the temperate soil being the quickest $(p<0.001)$, followed by the meadow organic soil $(p=0.012)$ and then the meadow mineral soil ( $p=0.003$ ), with the heath soil having the slowest turnover ( $p$ Table $2 k_{1}$ control 1; Fig. 6). In contrast, no significant difference in turnover rate was observed between soil types for the amino acid substrate (Table $3 k_{1}$ control 1; Fig. 6). The turnover of glucose showed some difference between soil types. Glucose turnover in the temperate soil was slower than in the meadow soils ( $p<0.001$ for both), whilst the heath soil had a significantly slower glucose turnover than the meadow mineral soil ( $p=0.027$; Table 4 $k_{1}$ control 1; Fig. 6). The rate constant for the second, slower C pool $\left(k_{2}\right)$ was not significantly different in any soil type for amino acids, but for trialanine the heath mineral soil had a significantly greater $k_{2}$ than the meadow mineral soil and the temperate soil $(p=0.004$ and $p<0.001$, respectively; Table $2 k_{2}$ control 1; Fig. 6). For glucose, the turnover of the second $\mathrm{C}$ pool in the temperate soil was slower than in both meadow soils $(p=0.007$ and $p<0.001$ for the mineral and organic soil, respectively; Table $4 k_{2}$ control 1 ; Fig. 6).

The partitioning of glucose- and trialanine-derived $\mathrm{C}$ into either slowly respired $\mathrm{C}$ (parameter $a_{2}$-indicative of allocation to biosynthesis or mineral sorption) or immediate respiration (parameter $a_{1}$ ) was different between the soil types. The temperate soil showed a lower proportion of glucose-derived $\mathrm{C}$ allocated to rapid respiration than soil from the meadow site $\left(p<0.001\right.$ for both; Table $4 a_{1}$ control 1; Fig. 7). However, proportionally more trialanine was initially used for respiration in the temperate soil than in the Arctic soils $(p=0.014, p=0.006$ and $p<0.001$, for the meadow mineral, meadow organic and heath soils, respectively; Table $2 a_{1}$ control 1; Fig. 7). The allocation of amino acid-derived $\mathrm{C}$ was not significantly different between soil types ( $p>0.05$; Table $3 a_{1}$ control 1; Fig. 7). 
Fig. 2 Depletion of ${ }^{14} \mathrm{C}-$ added as trialanine-in Arctic tundra soils: Heath mineral soil (a, b), Meadow mineral soil (c, d) and Meadow organic soil (e, f) after they had been subjected to $1(\mathbf{a}, \mathbf{c}, \mathbf{e})$ or $3(\mathbf{b}, \mathbf{d}$,

f) freeze-thaw cycles $(-7.5$ to $\left.+5{ }^{\circ} \mathrm{C}\right)$. The results are fitted with a double first-order exponential decay equation. Error bars indicate \pm 1SE

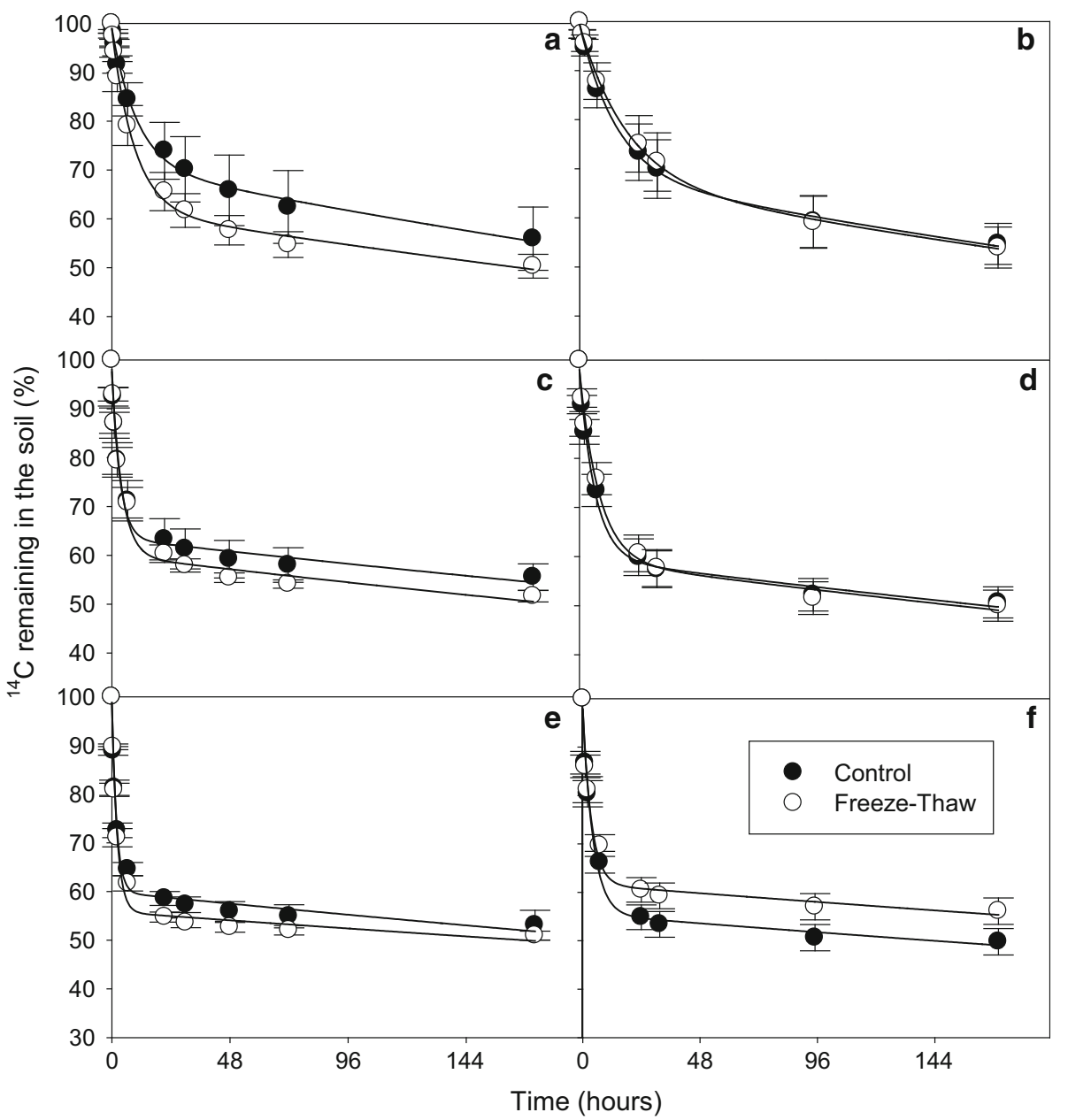

\section{Influence of freeze-thaw cycles on substrate mineralisation}

Freeze-thaw treatment only had a significant effect on mineralisation parameter $k_{1}$ when comparing all soil and substrates ( $p=0.043)$, but there were significant interactions between soil and FT treatment for all parameters except $k_{2}$ ( $p=0.001,0.034,0.013$ for parameters $a_{1}, k_{1}$ and $a_{2}$ ). The FT treatment had little effect on the mineralisation parameters in the Arctic soils (Figs. 2, 3, 4, 5; Tables 2, 3, 4, significant difference indicated by *). The Arctic soils showed no significant difference between the FTC treatment and its control for any substrate after either 1 or 3 FT cycle. However, it should be mentioned that there was relatively large variability between replicate results, particularly for the heath mineral soil, which might have obscured any treatment effects.

The temperate soil showed a greater response to FT treatment than the Arctic soils (Figs. 2, 3, 4, 5) with FT having a significant effect for $a_{1}, k_{1}$ and $a_{2}(p<0.001$, $p=0.013$ and $p<0.001$, respectively). There was also significant interaction between FT treatment and substrate for all mineralisation parameters $(p<0.001)$. For all three substrates, the rate constant $k_{1}$ was significantly affected by FTC. It decreased for both trialanine and amino acids significantly or almost significantly after both 1 and 3 FTC (by $0.20 \pm 0.05 \quad(p=0.005)$ and $0.08 \pm 0.02 \mathrm{~h}^{-1}$ $(p=0.103)$ after 1FTC and by $0.25 \pm 0.06(p=0.055)$ and $0.06 \pm 0.01 \mathrm{~h}^{-1}(p=0.001)$ after 3FTC, for trialanine and amino acids, respectively). The rate constant $k_{1}$ for glucose increased after the first cycle, but appears to decrease after 3FTC although there was also an increase in the controls $k_{1}$ over time. For glucose, the amount of substrate $\mathrm{C}$ allocated to pools $a_{1}$ and $a_{2}$ changed after both 1 and 3FTC $\left(a_{1}\right.$ decreased by $2.76 \pm 0.03$ and $1.85 \pm 0.20 \%(p<0.001$ for both $)$ after 1 and 3FTC, respectively). For amino acids and trialanine, the amount of $\mathrm{C}$ allocated to pools $a_{1}$ and $a_{2}$ were only significantly affected by 1FTC (trialanine- $a_{1}$ increased by $8.00 \pm 1.34 \% \quad(p<0.001)$, alanine- $a_{1}$ increased by $2.51 \pm 0.53 \%(p=0.023)$. A greater proportion of the trialanine and amino acid-derived $\mathrm{C}$ was allocated to initial respiration (pool $a_{1}$ ), whilst the opposite effect was observed in glucose. For glucose, the rate constant for the 
Fig. 3 Depletion of ${ }^{14} \mathrm{C}-$ added as amino acids - in Arctic tundra soils: Heath mineral soil (a, b), Meadow mineral soil (c, d) and Meadow organic soil (e, f) after they had been subjected to $1(\mathbf{a}, \mathbf{c}, \mathbf{e})$ or $3(\mathbf{b}, \mathbf{d}$,

f) freeze-thaw cycles $(-7.5$ to $+5{ }^{\circ} \mathrm{C}$ ). The results are fitted with a double first-order exponential decay equation. Error bars indicate $\pm 1 \mathrm{SE}$

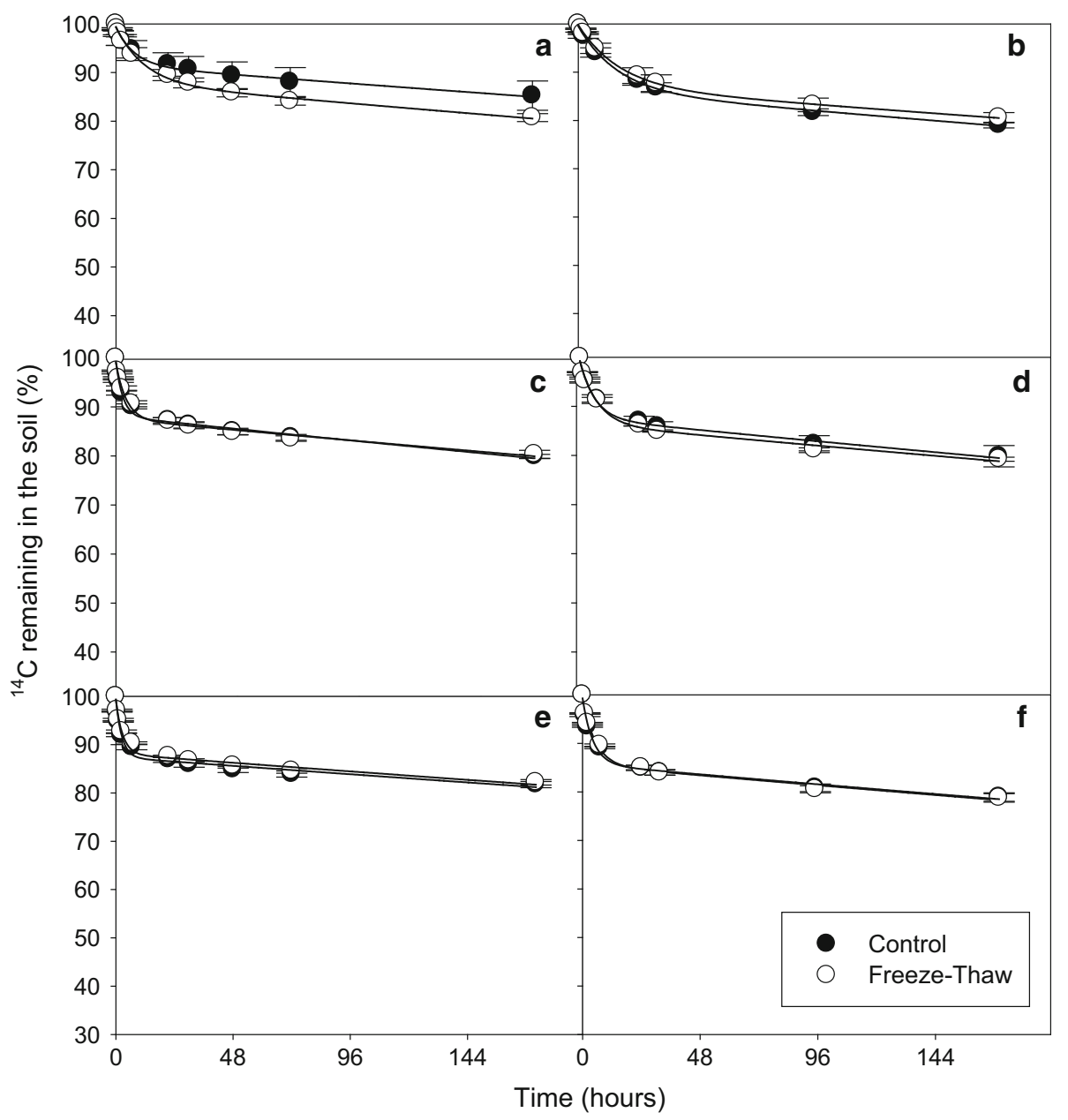

second C pool $\left(k_{2}\right)$ was significantly lower after 1FTC (by $\left.0.16 \pm 0.01 \times 10^{-3} \mathrm{~h}^{-1}\right)$; for the other substrates, $k_{2}$ was not significantly affected $(p>0.05)$. There was significant interaction in the temperate soil between substrate and treatment and time for $a_{1}, k_{1}$ and $a_{2}(p=0.037,<0.001$ and $=0.013$, respectively). Less of the observed differences between the 3FTC treatment and its associated control were significant than between 1FTC and its control. However, the only significant differences observed between the 1FTC treatment and the 3FTC treatment were in $k_{1}$ and $k_{2}$ for glucose, and the change observed was not as large as the insignificant change between their respective controls.

\section{Discussion}

\section{Freeze-thaw effects on $\mathbf{C}$ mineralisation in different soils}

Although the changes in $\mathrm{C}$ mineralisation we observed here in response to FTC were very small, in agreement with our initial hypothesis, temperate soils seem to be more susceptible to FTC than Arctic soils. Freezing can reduce substrate and water supply to microbes, causing starvation and desiccation, whilst subsequent thawing can induce a rapid change in the osmotic gradient, leading to cell lysis (Wilson and Walker 2010). Previous studies have suggested that FTC are most damaging when the microbial community is not adapted to them and where the freezing temperature is more extreme than they would naturally experience (Stres et al. 2010; Wilson and Walker 2010). The freezing temperatures used in this study are similar to minimum winter soil temperatures experienced at the Arctic sites in 2012-2013, although they are colder than soil temperatures experienced in $2013-2014\left(-3{ }^{\circ} \mathrm{C}\right.$ at the meadow site and $-4{ }^{\circ} \mathrm{C}$ at the heath site), which was a milder year with deeper snow cover [max-131 cm, $45 \mathrm{~cm}$ at Ny-Ålesund in 2013-2014 and 2012-2013, respectively (Norwegian Meteorological Institute Statistics)]. The temperate soil rarely experiences freezing temperatures or snow cover. However, as some characteristics of the temperate soil were different to Arctic soils (Table 1), namely DON, DOC, MBC and potentially others that have not 
Fig. 4 Depletion of ${ }^{14} \mathrm{C}-$ added as glucose-in Arctic tundra soils: Heath mineral soil (a, b), Meadow mineral soil (c, d) and Meadow organic soil (e, f) after they had been subjected to $1(\mathbf{a}, \mathbf{c}, \mathbf{e})$ or $3(\mathbf{b}, \mathbf{d}$,

f) freeze-thaw cycles $(-7.5$ to $+5{ }^{\circ} \mathrm{C}$ ). The results are fitted with a double first-order exponential decay equation. Error bars indicate $\pm 1 \mathrm{SE}$

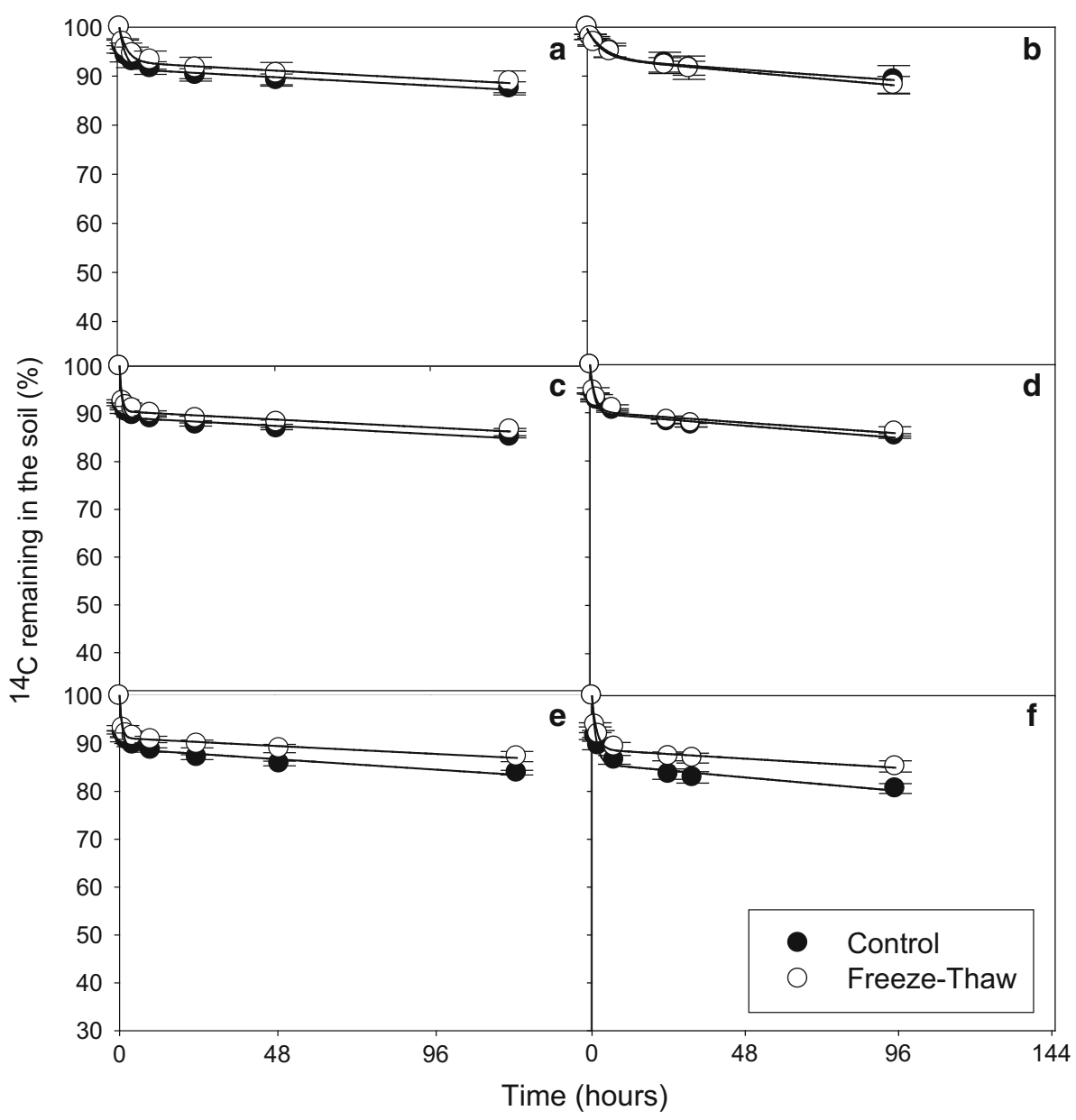

been measured, there could be an alternative explanation for the greater effect shown by temperate soils. For example, different nutrient availabilities in the temperate soils could support a more active microbial community, which is damaged more by FTC, as suggested by Schimel and Clein (1996).

The mineralisation parameters could be affected by substrate being adsorbed to soil particles. Guggenberger and Kaiser (2003) argued that in soil, mineral grains are already largely covered in organic materials and microbes, which would greatly reduce the capacity of minerals to adsorb fresh OM. This is supported by studies showing rapid microbial uptake of LMW-DOC compounds (Hill et al. 2008, 2012). However, Guggenberger and Kaiser (2003) also argued that younger, low organic C soil had more capacity to take up DOC. Therefore, some mineral adsorption could have occurred in the Arctic soils, which may have dampened the effect of FTC.

There is some tentative evidence that suggests substrate mineralisation was less effected after 3FTC than after 1 FTC as an interaction was observed between substrate, FT treatment and time. This is similar to some past studies where the adverse effects of FT have been shown to decrease with repeated cycles (Skogland et al. 1988; Larsen et al. 2002; Goldberg et al. 2008; Yu et al. 2011), although Schimel and Clein (1996) suggested that up to 3 repeated FT might still have a damaging effect, and other studies show maximum effect after 2FTC (Morley et al. 1983; Koponen et al. 2006; Yu et al. 2011). Whilst adverse effects decrease, significant recovery of microbial biomass during repeated FTC has not been observed (Morley et al. 1983; Skogland et al. 1988). There was no evidence that 3FTC has more of an effect than 1FTC in any of the soils.

\section{Substrate-specific freeze-thaw effects in the temperate soil}

The changes in mineralisation parameters for amino acids and trialanine were consistent with each other. The changes for glucose differed to the other compounds and were less consistent. Where the kinetic parameter $k_{1}$ was affected, it decreased for amino acids and trialanine. For glucose, there was no trend in the change in $k_{1}$. For amino acids and trialanine, $a_{1}$ increased due to FT and $a_{2}$ decreased, whilst 
Fig. 5 Depletion of ${ }^{14} \mathrm{C}-$ added as ${ }^{14} \mathrm{C}$-trialanine $(\mathbf{a}, \mathbf{b})$, ${ }^{14} \mathrm{C}$-amino acids $(\mathbf{c}, \mathbf{d})$ and ${ }^{14} \mathrm{C}$ glucose $(\mathbf{e}, \mathbf{f})$ in temperate grassland soils after they had been subjected to $1(\mathbf{a}, \mathbf{c}, \mathbf{e})$ or 3 $(\mathbf{b}, \mathbf{d}, \mathbf{f})$ freeze-thaw cycles $\left(-7.5\right.$ to $\left.+5{ }^{\circ} \mathrm{C}\right)$. The results are fitted with a double first-order exponential decay equation. Error bars indicate $\pm 1 \mathrm{SE}$

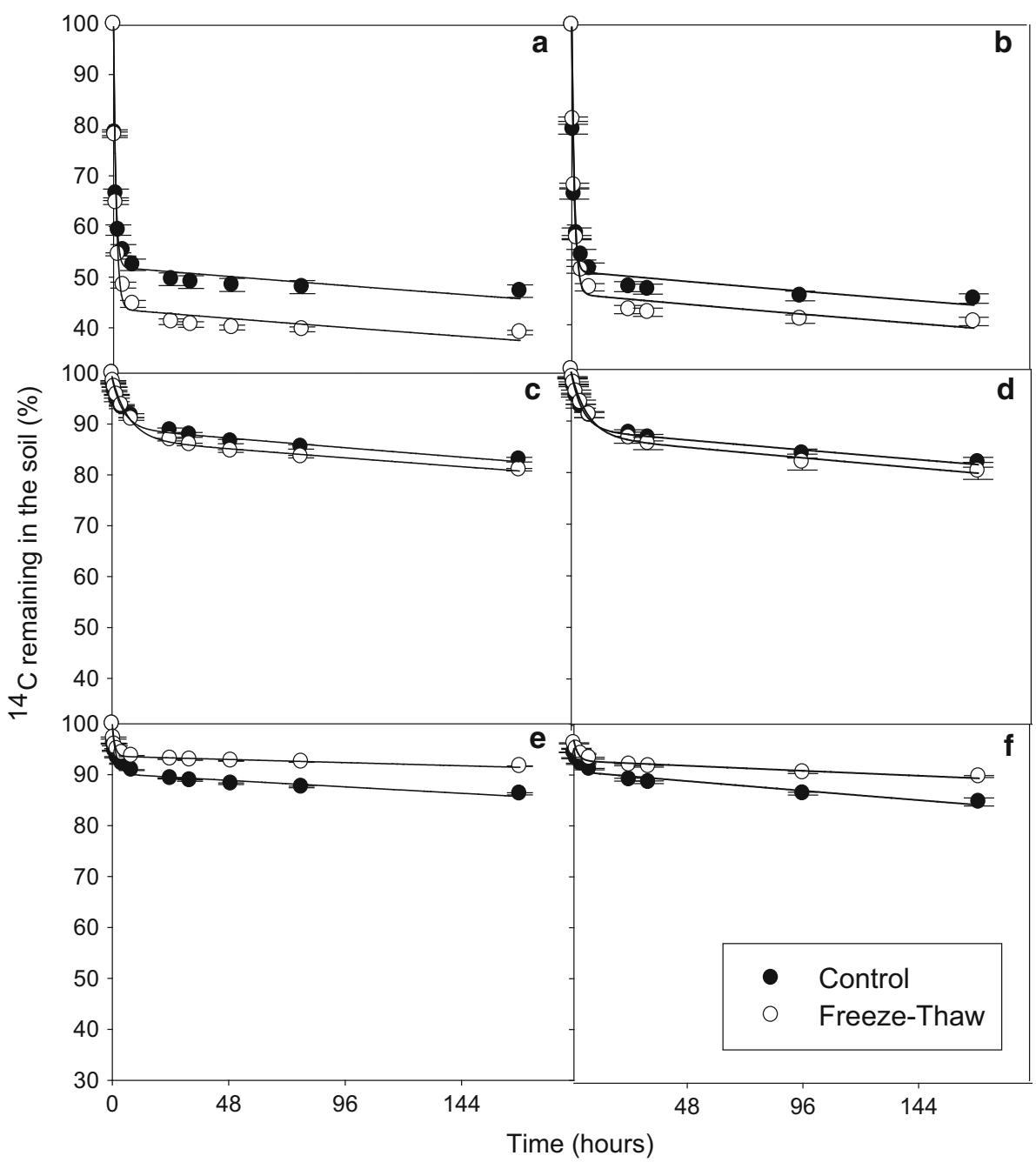

the opposite result was observed for glucose. This, combined with the $k_{1}$ results, suggests that more trialanine and amino acids were used for mineralisation, but they were used more slowly. The $k_{2}$ parameter was only affected by FT for glucose in the temperate soil, where it significantly decreased.

It is unlikely that any change in the mineralisation parameters was caused by a change in microbial community structure, size or activity as these have been shown to have little effect on LMW DOC mineralisation (Jones 1999; Strickland et al. 2010; Rousk et al. 2011). Jones et al. (2005, 2009) found the use of amino acids and peptides to be widespread amongst soil micro-organisms so it is unlikely that a change in community would affect usage.

Strickland et al. (2010) found that P availability was important in predicting glucose mineralisation, in addition to land use and plant cover. FTC could potentially liberate organic phosphate compounds by cell lysis or soil-bound phosphates by the break-up of soil aggregates (Freppaz et al. 2007). This would be likely to increase the mineralisation rate as was observed for glucose after 1FT, but that is not seen here for amino acids or trialanine. It is possible that the disintegration of soil aggregates could create fresh surfaces for phosphates to bind with, which could reduce the mineralisation rate (Özgül et al. 2012). Fresh surfaces could also have bound the added substrate, reducing the ${ }^{14} \mathrm{C}$ available for mineralisation. This could lead to a decrease in $a_{1}$ and an increase in $a_{2}$, but this was only observed for glucose.

Increases in the concentration of LMW DOC components due to FT could increase turnover time as there could be competition for uptake transporters (Jones and Hodge 1999). Farrell et al. (2014) found a decrease in trialanine uptake when very high glucose concentrations (9 mM) were added, which could occur close to areas of cellular lysis after FTC. However, decreased uptake should cause an increase in $a_{2}$, which was not observed for trialanine or amino acids. Uptake rate from soil has been considered to be equal to $k_{1}$ multiplied by the concentration of substrate in solution (Farrell et al. 2011). Thus, an increase in soil 
Fig. 6 Rate constants (a, c, e parameter $k_{1} ; \mathbf{b}, \mathbf{d}, \mathbf{f}$ parameter $k_{2}$ ) of each soil type after addition of ${ }^{14} \mathrm{C}$-trialanine $(\mathbf{a}, \mathbf{b})$, ${ }^{14} \mathrm{C}$-amino acids $(\mathbf{c}, \mathbf{d})$ and ${ }^{14} \mathrm{C}$ glucose $(\mathbf{e}, \mathbf{f})$ in the first control sample set. Letters reveal significant difference within each parameter comparing across soil and substrate $(p<0.05)$. Error bars indicate $\pm 1 \mathrm{SE}$

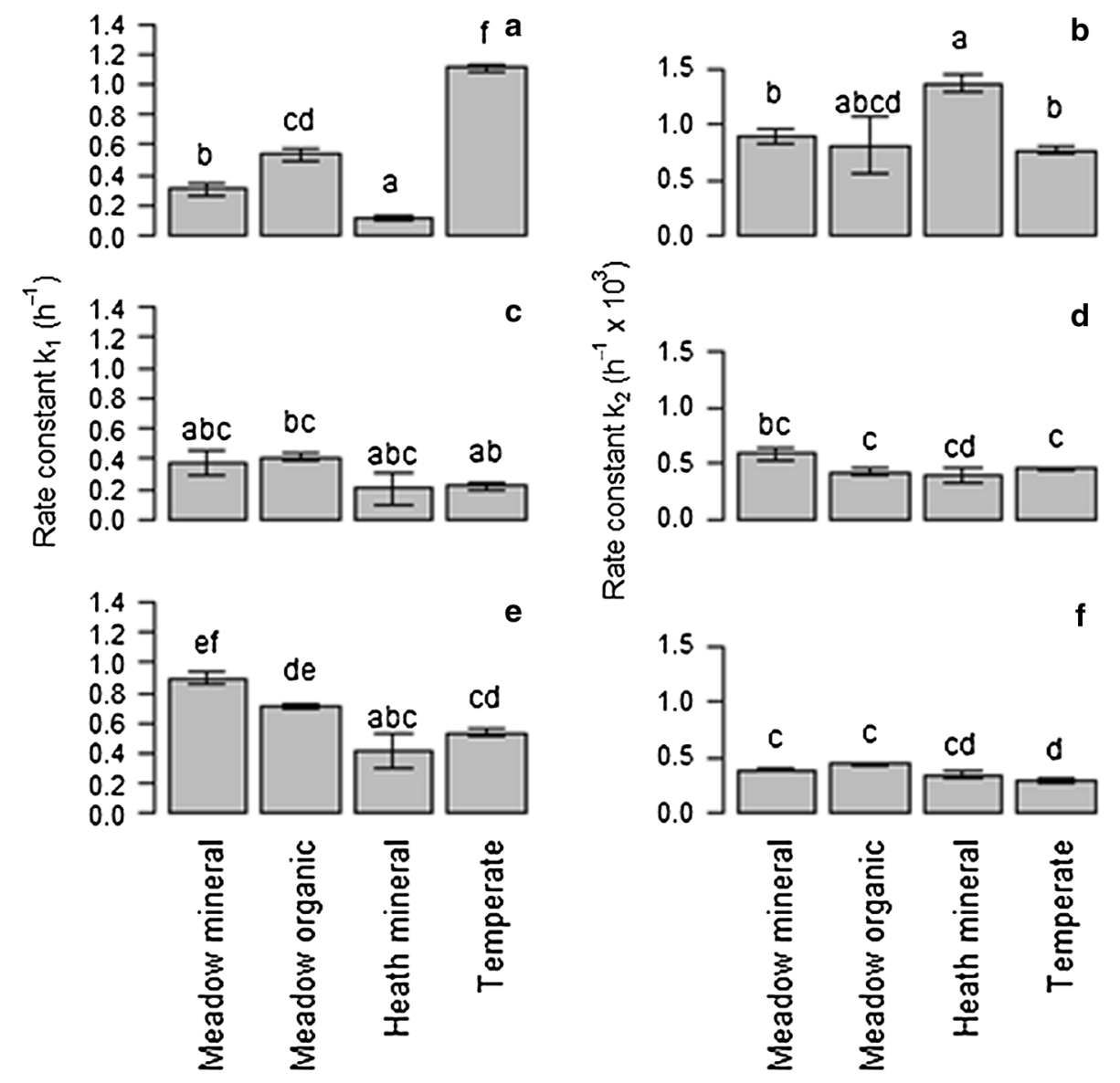

substrate concentration caused by FTC could lead to an increase in microbial uptake rate despite a decrease in $k_{1}$.

If one assumes that $a_{2}$ represents substrate used for biosynthesis whilst $a_{1}$ is the proportion of substrate used for catabolism, an assessment of $\mathrm{C}$ use efficiency can be made. For the temperate soil, where the changes in mineralisation parameters were observed due to FTC, this is a fair assumption as rapid microbial uptake, but little mineral sorption of LMW-DOC compounds has been observed (Hill et al. 2008, 2012). For amino acids and trialanine, a decrease in $\mathrm{C}$ use efficiency appears to have occurred as more substrate was used for respiration than growth. This could be consistent with a lag phase after FT. Such a lag phase was shown in the results of Drotz et al. (2010). The opposite result was observed for glucose making a lag phase less likely. However, glucose can be used by, or to make metabolites for, most bacterial metabolic systems (Cartledge et al. 1992). It is possible that opposing results could be caused by differences in internal substrate use. Amino acids and trialanine could also be used as an $\mathrm{N}$ source should the $\mathrm{C} / \mathrm{N}$ ration be high. This could result in the $\mathrm{C}$ being used for respiration after the deamination (Apostel et al. 2013).
The $k_{2}$ parameter was only affected by FT for glucose in the temperate soil. In the instances, where this parameter was significantly affected it consistently decreased. The value of $k_{2}$ is dependent on the turnover of the microbial community, and this is influenced by a number of factors including grazing by organisms, such as protozoa, temperature, infection by viruses, heterolysis and substrate availability (Alexander 1981). It also depends on the biochemical pathway of the added substrate, for example the allocation of the substrate $\mathrm{C}$ into cell wall structures, that tend to be slower to degrade compared to cytoplasm material, such as metabolites (Malik et al. 2013). The $k_{2}$ value could also be affected by desorption of mineral bound $\mathrm{C}$, but, as mentioned above, it is unlikely that much sorption occurs in the temperate soil. The decrease in $k_{2}$ suggests a slower turnover time for biosynthesised glucose. If the microbial turnover had decreased, it would be expected that the $k_{2}$ values of amino acids and trialanine would also decrease. This is not the case. It seems more likely that the glucose was used to produce less readily degradable material after FT. Further research is required to identify whether this is the case. 


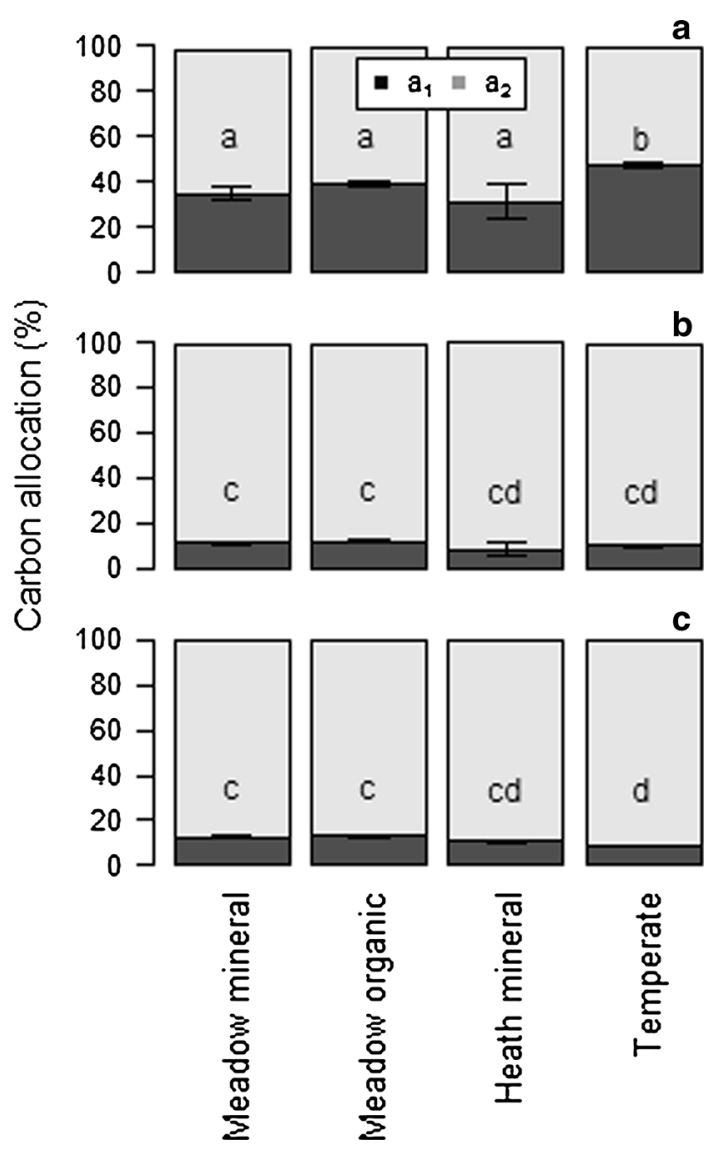

Fig. 7 Carbon allocation (parameters $a_{1}$ and $a_{2}$ ) in each soil and substrate after addition of ${ }^{14} \mathrm{C}$-trialanine (a), ${ }^{14} \mathrm{C}$-amino acids (b) and ${ }^{14} \mathrm{C}$-glucose (c) in the first control sample set. Letters reveal significant difference across soil and substrate $(p<0.05)$. Error bars indicate $\pm 1 \mathrm{SE}$

\section{C substrate turnover in soil}

C cycling in Arctic soils is typically dominated by the input and breakdown of plant residues (Bird et al. 2002). These residues are dominated by cellulose/hemicellulose and protein whose extracellular cleavage produces simple sugars, peptides and amino acids (Kögel-Knabner 2002). The results describing the mineralisation of these compounds in our Arctic soil were similar to those presented for tundra heath by Boddy et al. (2008) and clearly showed a rapid turnover of this $\mathrm{C}$ within the soil solution. The amino acid half-life $\left(t_{1 / 2}=\frac{\ln 2}{k_{1}}\right)$ for the temperate grassland calculated in our study $(3.2 \mathrm{~h})$ was similar to that measured by Jones et al. (2005) for the agricultural soil $(2.9 \mathrm{~h})$, but greater than that measured for a similar soil from the same location $(0.9 \mathrm{~h})$ (Jones et al. 2005). This could be due to the soils being collected at different times (Glanville et al. 2012) or the much shorter mineralisation measurement period and warmer incubation temperature used by Jones et al. (2005). Farrar et al. (2012) measured longer turnover times for glucose in a similar temperate grassland soil than was found here. Few studies have looked at peptide mineralisation despite their importance in soil C and N cycling. Farrell et al. (2011) found a slightly slower turnover of trialanine $\left(k_{1}=0.77 \mathrm{~h}^{-1}\right.$ (Farrell et al. 2011) compared to $1.11 \mathrm{~h}^{-1}$ ) in a similar temperate grassland soil to that used in our study. This is despite the fact that they used a higher incubation temperature $\left(10{ }^{\circ} \mathrm{C}\right.$ compared to $5^{\circ} \mathrm{C}$ ), which has been shown to increase $k_{1}$ in temperate soils (Jones 1999). The turnover of trialanine in the Arctic soils appears to be slower than any of the soils analysed by Farrell et al. $(2011,2013)$. This could be due to the lower experimental temperature and less available nutrients in the Arctic soils (Strickland et al. 2010; Farrell et al. 2013). Overall, we conclude our results describing substrate mineralisation in the control (non-FTC) soils are broadly similar to other studies providing confidence in this indicator to evaluate an FTC effect.

\section{Implications and experimental caveats}

Whilst the temperatures used in this study were representative of air temperature fluctuations typically experienced at the Arctic sites (Norwegian Meteorological Institute Statistics), it is unlikely that soils below the surface experience such extreme and rapid temperature fluctuations. They are insulated by surrounding soil and vegetation (Henry 2007). Furthermore, freezing and thawing soils require more energy than changing its temperature so a sustained period above freezing is required to fully thaw the soil even at the surface. FTC carried out over a narrow temperature range cause less damage than more intense freezing temperatures (Hentschel et al. 2008; Elliot and Henry 2009), so if a warmer freezing temperature had been used, we would have expected a smaller response. As little significant effect was observed at what was likely a relatively extreme FTC for these Arctic soils it appears that an increase in rapid air temperature fluctuations around $0{ }^{\circ} \mathrm{C}$ in the Arctic will have limited effect on the use of LMW DOC by soil microbes after thaw. It is possible that a longer freezing period than used in this experiment might have more effect on the microbial use of LMW DOC, since longer freezing periods have been shown to be more damaging to the microbial community than shorter freezing periods (Haei et al. 2011).

These results suggest rapid recovery of microbial utilisation of LMW-DOC after freezing in Arctic soils. This would likely lead to the rapid use of the compounds tested in this study if they were produced during FTC, with microbes being able to capitalise on any flux of LMWDOC. Therefore, it is unlikely that FTC or repeated FTC would cause increased leaching of these particular compounds. This might explain why some studies have found little effect of FTC on the aromaticity of DOC in leachate if they were thawed for days rather than hours (Hentschel 
Table 2 Modelled double firstorder kinetic parameters describing the mineralisation of ${ }^{14} \mathrm{C}$-labelled trialanine in Arctic and temperate soils subjected to 1 or 3 successive freeze-thaw (FT) cycles $\left(-7.5\right.$ to $\left.+5{ }^{\circ} \mathrm{C}\right)$ and their respective non-frozen controls

Table 3 Modelled double firstorder kinetic parameters that describe ${ }^{14} \mathrm{C}$-labelled amino acid mineralisation in Arctic and temperate soils subjected to 1 and 3 freeze-thaw (FT) cycles of -7.5 to $+5{ }^{\circ} \mathrm{C}$

\begin{tabular}{llcccc}
\hline Trialanine & \multicolumn{5}{c}{} \\
\hline Soil & Parameter & Control & FT & 3 Control & $3 \mathrm{FT}$ \\
\hline Meadow mineral & $a_{1}(\%)$ & $34.6 \pm 3.7$ & $37.8 \pm 1.4$ & $38.8 \pm 3.4$ & $39.9 \pm 0.9$ \\
& $k_{1}\left(\mathrm{~h}^{-1}\right)$ & $0.31 \pm 0.05$ & $0.24 \pm 0.08$ & $0.16 \pm 0.03$ & $0.13 \pm 0.03$ \\
& $a_{2}(\%)$ & $63.5 \pm 4.0$ & $60.1 \pm 1.4$ & $59.3 \pm 3.7$ & $58.2 \pm 0.9$ \\
& $k_{2}\left(\times 10^{-3} \mathrm{~h}^{-1}\right)$ & $0.88 \pm 0.06$ & $1.02 \pm 0.19$ & $1.03 \pm 0.07$ & $0.98 \pm 0.14$ \\
Meadow organic & $a_{1}(\%)$ & $39.4 \pm 1.2$ & $41.8 \pm 1.5$ & $43.2 \pm 1.5$ & $38.8 \pm 4.3$ \\
& $k_{1}\left(\mathrm{~h}^{-1}\right)$ & $0.54 \pm 0.04 !$ & $0.47 \pm 0.03$ & $0.24 \pm 0.02 !$ & $0.34 \pm 0.07$ \\
& $a_{2}(\%)$ & $59.3 \pm 1.1$ & $57.0 \pm 1.4$ & $54.9 \pm 2.7$ & $59.7 \pm 4.5$ \\
Heath mineral & $k_{2}\left(\times 10^{-3} \mathrm{~h}^{-1}\right)$ & $0.81 \pm 0.26$ & $0.68 \pm 0.05$ & $0.78 \pm 0.12$ & $0.66 \pm 0.05$ \\
& $a_{1}(\%)$ & $31.4 \pm 7.4$ & $29.6 \pm 10.1$ & $34.2 \pm 5.8$ & $34.1 \pm 3.9$ \\
& $k_{1}\left(\mathrm{~h}^{-1}\right)$ & $0.12 \pm 0.01$ & $0.22 \pm 0.15$ & $0.08 \pm 0.01$ & $0.06 \pm 0.01$ \\
& $a_{2}(\%)$ & $68.1 \pm 7.7$ & $69.6 \pm 10.4$ & $65.1 \pm 5.9$ & $65.3 \pm 4.0$ \\
& $k_{2}\left(\times 10^{-3} \mathrm{~h}^{-1}\right)$ & $1.37 \pm 0.09$ & $1.00 \pm 0.29$ & $1.33 \pm 0.11$ & $1.34 \pm 0.16$ \\
& $a_{1}(\%)$ & $47.43 \pm 1.2 *$ & $55.43 \pm 0.7 *$ & $48.87 \pm 1.2$ & $53.16 \pm 0.7$ \\
& $k_{1}\left(\mathrm{~h}^{-1}\right)$ & $1.1 \pm 0.03^{*}$ & $0.9 \pm 0.03 *$ & $1.1 \pm 0.06$ & $0.8 \pm 0.02$ \\
& $a_{2}(\%)$ & $52.01 \pm 1.2 * !$ & $43.73 \pm 0.7 *$ & $50.73 \pm 1.1 !$ & $46.17 \pm 0.8$ \\
& $k_{2}\left(\times 10^{-3} \mathrm{~h}^{-1}\right)$ & $0.8 \pm 0.04$ & $0.9 \pm 0.05$ & $0.8 \pm 0.01$ & $1.0 \pm 0.05$
\end{tabular}

* A statistical difference between freeze-thaw treatment and the control

! Statistical difference over time (i.e. between the first and third control or 1FT and 3FT), $(p<0.05)$. Values represent mean $\pm \operatorname{SE}(n=4)$

\begin{tabular}{llllll}
\hline Amino acids & \multicolumn{5}{l}{} \\
\hline Soil & Parameter & Control & FT & 3 Control & $3 \mathrm{FT}$ \\
\hline Meadow mineral & $a_{1}(\%)$ & $11.2 \pm 0.8$ & $11.5 \pm 0.7$ & $10.8 \pm 0.8$ & $12.9 \pm 0.2$ \\
& $k_{1}\left(\mathrm{~h}^{-1}\right)$ & $0.37 \pm 0.08$ & $0.24 \pm 0.04$ & $0.15 \pm 0.03$ & $0.14 \pm 0.02$ \\
& $a_{2}(\%)$ & $88.1 \pm 0.8$ & $87.5 \pm 0.7$ & $88.4 \pm 0.8$ & $86.2 \pm 0.2$ \\
& $k_{2}\left(\times 10^{-3} \mathrm{~h}^{-1}\right)$ & $0.59 \pm 0.06$ & $0.53 \pm 0.07$ & $0.47 \pm 0.15$ & $0.53 \pm 0.03$ \\
Meadow organic & $a_{1}(\%)$ & $12.0 \pm 0.7$ & $11.2 \pm 0.3 !$ & $13.3 \pm 0.5$ & $13.7 \pm 0.5 !$ \\
& $k_{1}\left(\mathrm{~h}^{-1}\right)$ & $0.41 \pm 0.03 !$ & $0.37 \pm 0.05$ & $0.22 \pm 0.02 !$ & $0.19 \pm 0.02$ \\
& $a_{2}(\%)$ & $87.4 \pm 0.7$ & $88.1 \pm 0.4 !$ & $85.9 \pm 0.6$ & $85.5 \pm 0.5 !$ \\
Heath mineral & $k_{2}\left(\times 10^{-3} \mathrm{~h}^{-1}\right)$ & $0.43 \pm 0.03$ & $0.44 \pm 0.02$ & $0.54 \pm 0.04$ & $0.52 \pm 0.03$ \\
& $a_{1}(\%)$ & $8.6 \pm 2.5$ & $12.1 \pm 0.5$ & $13.5 \pm 0.3$ & $12.9 \pm 1.7$ \\
& $k_{1}\left(\mathrm{~h}^{-1}\right)$ & $0.20 \pm 0.11$ & $0.10 \pm 0.04$ & $0.11 \pm 0.04$ & $0.06 \pm 0.01$ \\
& $a_{2}(\%)$ & $90.9 \pm 2.6$ & $87.4 \pm 0.4$ & $86.0 \pm 0.4$ & $86.9 \pm 1.6$ \\
& $k_{2}\left(\times 10^{-3} \mathrm{~h}^{-1}\right)$ & $0.39 \pm 0.06$ & $0.47 \pm 0.04$ & $0.55 \pm 0.02$ & $0.45 \pm 0.04$ \\
& $a_{1}(\%)$ & $9.9 \pm 0.5 *$ & $12.4 \pm 0.3 *$ & $11.0 \pm 0.6$ & $12.5 \pm 1.0$ \\
& $k_{1}\left(\mathrm{~h}^{-1}\right)$ & $0.22 \pm 0.02$ & $0.14 \pm 0.00$ & $0.21 \pm 0.01 *$ & $0.15 \pm 0.01 *$ \\
& $a_{2}(\%)$ & $89.2 \pm 0.5 *$ & $86.9 \pm 0.3 *$ & $88.3 \pm 0.6$ & $86.9 \pm 1.1$ \\
& $k_{2}\left(\times 10^{-3} \mathrm{~h}^{-1}\right)$ & $0.46 \pm 0.01$ & $0.44 \pm 0.01$ & $0.47 \pm 0.03$ & $0.50 \pm 0.05$
\end{tabular}

The parameters $a_{1}$ and $a_{2}$ are the proportion of substrate mineralised rapidly or slowly, whilst $k_{1}$ and $k_{2}$ are their respective rate constants

* A statistical difference between freeze-thaw treatment and the control (not frozen)

! Statistical difference over time (i.e. between the first and third control or 1FT and 3FT), $(p<0.05)$. Values represent mean $\pm \operatorname{SE}(n=4)$ et al. 2008; Vestgarden and Austnes 2009). Rapid recovery of microbes might mean that they could out-compete plants for any LMW organic N produced after FTC. Arctic plants can recover in $12 \mathrm{~h}$ from mild freezing and grow in frozen soil, but how rapidly they recover from more intense FTC needs to be determined to show whether this is the case 
Table 4 Modelled double firstorder kinetic parameters that describe the mineralisation of ${ }^{14} \mathrm{C}$-labelled glucose in Arctic and temperate soils subjected to 1 and 3 freeze-thaw (FT) cycles $\left(-7.5\right.$ to $\left.+5{ }^{\circ} \mathrm{C}\right)$

\begin{tabular}{lllllc}
\hline Glucose & \multicolumn{5}{c}{} \\
\hline Soil & Parameter & 1 Control & $1 \mathrm{FT}$ & 3 Control & $3 \mathrm{FT}$ \\
\hline Meadow mineral & $a_{1}(\%)$ & $12.6 \pm 0.3 !$ & $11.3 \pm 0.6$ & $10.4 \pm 0.3 !$ & $10.1 \pm 0.6$ \\
& $k_{1}\left(\mathrm{~h}^{-1}\right)$ & $0.89 \pm 0.04 !$ & $0.89 \pm 0.06 !$ & $0.66 \pm 0.05 !$ & $0.56 \pm 0.06 !$ \\
& $a_{2}(\%)$ & $87.2 \pm 0.3 !$ & $88.1 \pm 0.6$ & $89.3 \pm 0.3 !$ & $89.6 \pm 0.6$ \\
& $k_{2}\left(\times 10^{-3} \mathrm{~h}^{-1}\right)$ & $0.39 \pm 0.01$ & $0.38 \pm 0.03$ & $0.41 \pm 0.04$ & $0.34 \pm 0.04$ \\
Meadow organic & $a_{1}(\%)$ & $13.1 \pm 0.5$ & $10.7 \pm 0.7$ & $14.0 \pm 1.0$ & $11.1 \pm 0.9$ \\
& $k_{1}\left(\mathrm{~h}^{-1}\right)$ & $0.72 \pm 0.01$ & $0.89 \pm 0.05$ & $0.67 \pm 0.03$ & $0.68 \pm 0.05$ \\
& $a_{2}(\%)$ & $86.6 \pm 0.5$ & $89.1 \pm 0.7$ & $85.8 \pm 1.1$ & $88.8 \pm 0.9$ \\
Heath mineral & $k_{2}\left(\times 10^{-3} \mathrm{~h}^{-1}\right)$ & $0.44 \pm 0.02$ & $0.36 \pm 0.04$ & $0.72 \pm 0.01$ & $0.46 \pm 0.06$ \\
& $a_{1}(\%)$ & $10.7 \pm 0.9$ & $9.1 \pm 2.1$ & $6.0 \pm 1.9$ & $5.9 \pm 1.2$ \\
& $k_{1}\left(\mathrm{~h}^{-1}\right)$ & $0.41 \pm 0.11$ & $0.34 \pm 0.07$ & $0.19 \pm 0.02$ & $0.24 \pm 0.04$ \\
& $a_{2}(\%)$ & $89.0 \pm 1.0$ & $90.3 \pm 2.2$ & $93.5 \pm 2.0$ & $93.8 \pm 1.3$ \\
& $k_{2}\left(\times 10^{-3} \mathrm{~h}^{-1}\right)$ & $0.35 \pm 0.03$ & $0.34 \pm 0.03 !$ & $0.51 \pm 0.1$ & $0.66 \pm 0.08 !$ \\
& $a_{1}(\%)$ & $8.9 \pm 0.1 *$ & $6.2 \pm 0.1 *$ & $8.6 \pm 0.3 *$ & $6.8 \pm 0.2 *$ \\
& $k_{1}\left(\mathrm{~h}^{-1}\right)$ & $0.54 \pm 0.03^{*}$ & $0.93 \pm 0.08^{*} !$ & $0.70 \pm 0.06$ & $0.55 \pm 0.03 !$ \\
& $a_{2}(\%)$ & $90.2 \pm 0.1 *$ & $93.6 \pm 0.1 *$ & $90.7 \pm 0.4 *$ & $92.8 \pm 0.2 *$ \\
& $k_{2}\left(\times 10^{-3} \mathrm{~h}^{-1}\right)$ & $0.30 \pm 0.01^{*}$ & $0.14 \pm<0.01^{*} !$ & $0.44 \pm 0.07$ & $0.22 \pm 0.01 !$ \\
\hline
\end{tabular}

The parameters $a_{1}$ and $a_{2}$ are the proportion of substrate mineralised rapidly or slowly, whilst $k_{1}$ and $k_{2}$ are their respective rate constants

* A statistical difference between freeze-thaw treatment and the control (not frozen)

! Statistical difference over time (i.e. between the first and third control or 1FT and 3FT), $(p<0.05)$. Values represent mean $\pm \mathrm{SE}(n=4)$
(Billings et al. 1977). Whether microbial utilisation of larger compounds and other microbial processes recovers as quickly as their use of LMW-DOC could be further investigated.

\section{Conclusions}

The aims of this study were to identify whether FTC caused any change in the dynamics of LMW DOC mineralisation. The results described above indicate that short FTC induces a small change in LMW DOC mineralisation on soil from a temperate environment. However, FTC appeared to have little effect on the mineralisation of LMW DOC in Arctic soils. Therefore, it seems unlikely that an increase in Arctic FTC will directly affect the microbial utilisation of LMW DOC after FTC.

The changes in modelled mineralisation parameters due to FT, observed in the temperate soil, varied with the LMW DOC compound. The changes observed for amino acids and trialanine were consistent with each other, showing longer turnover times and more $\mathrm{C}$ immediately allocated to respiration after FT. The response for glucose to FT was less clear, and the change in $\mathrm{C}$ allocation was opposite to that of amino acids and trialanine, with a lower proportion of the $\mathrm{C}$ allocated to respiration due to FT. The reason for this difference requires further investigation.

Acknowledgments This work was funded by the UK Natural Environment Research Council. We thank Jonathan Roberts for helping with the sample analysis in the UK and Nick Cox for helping with the sample collection near Ny-Ålesund, Svalbard, at the NERC Arctic Station.

\section{Compliance with ethical standards}

Conflict of interest The authors declare that they have no conflict of interest.

Open Access This article is distributed under the terms of the Creative Commons Attribution 4.0 International License (http://creative commons.org/licenses/by/4.0/), which permits unrestricted use, distribution, and reproduction in any medium, provided you give appropriate credit to the original author(s) and the source, provide a link to the Creative Commons license, and indicate if changes were made.

\section{References}

Alexander M (1981) Why microbial predators and parasites do not eliminate their prey and hosts. Annu Rev Microbiol 35:113-133

Anisimov OA, Vaughan DG, Callaghan TV, Furgal C, Marchant H, Prowse TD, Vilhjálmsson H, Walsh JE (2007) Polar regions (Arctic and Antarctic). Climate change 2007: impacts, adaptation and vulnerability. In: Parry ML, Canziani OF, Palutikof JP, van der Linden PJ, Hanson CE (eds) Contribution of Working 
Group II to the Fourth Assessment Report of the Intergovernmental Panel on Climate Change. Cambridge University Press, Cambridge, pp 653-685

Apostel C, Dippold M, Glaser B, Kuzyakov Y (2013) Biochemical pathways of amino acids in soil: assessment by position-specific labeling and 13 C-PLFA analysis. Soil Biol Biochem 67:31-40

Batjes NH (1996) Total carbon and nitrogen in the soils of the world. Eur J Soil Sci 47:151-163

Billings WD, Peterson KM, Shaver GR, Trent AW (1977) Root growth, respiration, and carbon dioxide evolution in an Arctic tundra soil. Arct Alp Res 9:129-137

Bird M, Santruckova H, Lloyd J, Lawson E (2002) The isotopic composition of soil organic carbon on a north-south transect in western Canada. Eur J Soil Sci 53:393-403

Boddy E, Hill PW, Farrar J, Jones DL (2007) Fast turnover of low molecular weight components of the dissolved organic carbon pool of temperate grassland field soils. Soil Biol Biochem 39:827-835

Boddy E, Roberts P, Hill PW, Farrar J, Jones DL (2008) Turnover of low molecular weight dissolved organic $\mathrm{C}$ (DOC) and microbial $\mathrm{C}$ exhibit different temperature sensitivities in Arctic tundra soils. Soil Biol Biochem 40:1557-1566

Cartledge TG, Jenkins RO, Leach CK (1992) Biosynthesis and the integration of cell metabolism. Butterworth-Heinemann, Oxford

Degens BP, Schipper LA, Sparling GP, Duncan LC (2001) Is the microbial community in a soil with reduced catabolic diversity less resistant to stress or disturbance? Soil Biol Biochem 33:1143-1153

Drotz SH, Sparrman T, Nilsson MB, Schleucher J, Öquist MG (2010) Both catabolic and anabolic heterotrophic microbial activity proceed in frozen soils. Proc Natl Acad Sci USA 107:21046-21051

Elliott AC, Henry HAL (2009) Freeze-thaw cycle amplitude and freezing rate effects on extractable nitrogen in a temperate old field soil. Biol Fertil Soils 45:469-476

Farrar J, Boddy E, Hill PW, Jones DL (2012) Discrete functional pools of soil organic matter in a UK grassland soil are differentially affected by temperature and priming. Soil Biol Biochem 49:52-60

Farrell M, Hill PW, Wanniarachchi SD, Farrar J, Bardgett RD, Jones DL (2011) Rapid peptide metabolism: a major component of soil nitrogen cycling? Glob Biogeochem Cycles 25:GB3014

Farrell M, Hill PW, Farrar J, DeLuca TH, Roberts P, Kielland K, Dahlgren R, Murphy DV, Hobbs PJ, Bardgett RD, Jones DL (2013) Oligopeptides represent a preferred source of organic $\mathrm{N}$ uptake: a global phenomenon? Ecosystems 16:133-145

Farrell M, Prendergast-Miller M, Jones DL, Hill PW, Condron LM (2014) Soil microbial organic nitrogen uptake is regulated by carbon availability. Soil Biol Biochem 77:261-267

Feng X, Nielsen LL, Simpson MJ (2007) Responses of soil organic matter and microorganisms to freeze-thaw cycles. Soil Biol Biochem 39:2027-2037

Førland EJ, Benestad R, Hanssen-Bauer I, Haugen JE, Skaugen TE (2011) Temperature and precipitation development at Svalbard 1900-2100. Adv Meteorol 2011:893790

Freppaz M, Williams BL, Edwards AC, Scalenghec R, Zanini E (2007) Simulating soil freeze/thaw cycles typical of winter alpine conditions: implications for $\mathrm{N}$ and $\mathrm{P}$ availability. Appl Soil Ecol 35:247-255

Fujii K, Hayakawa C, Van Hees PAW, Funakawa S, Kosaki T (2010) Biodegradation of low molecular weight organic compounds and their contribution to heterotrophic soil respiration in three Japanese forest soils. Plant Soil 334:475-489

Glanville H, Rousk J, Golyshin P, Jones DL (2012) Mineralization of low molecular weight carbon substrates in soil solution under laboratory and field conditions. Soil Biol Biochem 48:88-95
Goldberg SD, Muhr J, Borken W, Gebauer G (2008) Fluxes of climate-relevant trace gases between a Norway spruce forest soil and atmosphere during repeated freeze-thaw cycles in mesocosms. J Plant Nutr Soil Sci 171:729-739

Grogan P, Michelsen A, Ambus P, Jonasson S (2004) Freeze-thaw regime effects on carbon and nitrogen dynamics in sub-Arctic heath tundra mesocosms. Soil Biol Biochem 36:641-654

Guggenberger G, Kaiser K (2003) Dissolved organic matter in soil: challenging the paradigm of sorptive preservation. Geoderma 113:293-310

Haei M, Rousk J, Ilstedt U, Öquist M, Bååth E, Laudon H (2011) Effects of soil frost on growth, composition and respiration of the soil microbial decomposer community. Soil Biol Biochem 43:2069-2077

Henry HAL (2007) Soil freeze-thaw cycle experiments: trends, methodological weaknesses and suggested improvements. Soil Biol Biochem 39:977-986

Henry HAL (2008) Climate change and soil freezing dynamics: historical trends and projected changes. Clim Change 87:421-434

Hentschel K, Borken W, Matzner E (2008) Repeated freeze-thaw events affect leaching losses of nitrogen and dissolved organic matter in a forest soil. J Plant Nutr Soil Sci 171:699-706

Herrmann A, Witter E (2002) Sources of C and N contributing to the flush in mineralization upon freeze-thaw cycles in soils. Soil Biol Biochem 34:1495-1505

Hill PW, Farrar JF, Jones DL (2008) Decoupling of microbial glucose uptake and mineralization in soil. Soil Biol Biochem 40:616-624

Hill PW, Farrell M, Jones DL (2012) Bigger may be better in soil N cycling: does rapid acquisition of small L-peptides by soil microbes dominate fluxes of protein-derived $\mathrm{N}$ in soil? Soil Biol Biochem 48:106-112

Hugelius G, Strauss J, Zubrzycki S, Harden JW, Schuur EAG, Ping CL, Schirrmeister L, Grosse G, Michaelson GJ, Koven CD, O’Donnell JA, Elberling B, Mishra U, Camill P, Yu Z, Palmtag J, Kuhry P (2014) Estimated stocks of circumpolar permafrost carbon with quantified uncertainty ranges and identified data gaps. Biogeosciences 11:6573-6593

Jones DL (1999) Amino acid biodegradation and its potential effects on organic nitrogen capture by plants. Soil Biol Biochem 31:613-622

Jones DL, Hodge A (1999) Biodegradation kinetics and sorption reactions of three differently charged amino acids in soil and their effects on plant organic nitrogen availability. Soil Biol Biochem 31:1331-1342

Jones DL, Kemmitt SJ, Wright D, Cuttle SP, Bol R, Edwards AC (2005) Rapid intrinsic rates of amino acid biodegradation in soils are unaffected by agricultural management strategy. Soil Biol Biochem 37:1267-1275

Jones DL, Kielland K, Sinclair FL, Dahlgren RA, Newsham KK, Farrar JF, Murphy DV (2009) Soil organic nitrogen mineralization across a global latitudinal gradient. Glob Biogeochem Cycles 23:GB1016

Kalbitz K, Schwesig D, Schmerwitz J, Kaiser K, Haumaier L, Glaser B, Ellerbrock R, Leinweber P (2003) Changes in properties of soil-derived dissolved organic matter induced by biodegradation. Soil Biol Biochem 35:1129-1142

Kögel-Knabner I (2002) The macromolecular organic composition of plant and microbial residues as inputs to soil organic matter. Soil Biol Biochem 34:139-162

Koponen HT, Jaakkola T, Keinanen-Toivola MM, Kaipainen S, Tuomainen J, Servomaa K, Martikainen PJ (2006) Microbial communities, biomass, and activities in soils as affected by freeze thaw cycles. Soil Biol Biochem 38:1861-1871

Larsen KS, Jonasson S, Michelsen A (2002) Repeated freeze-thaw cycles and their effects on biological processes in two Arctic ecosystem types. Appl Soil Ecol 21:187-195 
Lipson DA, Monson RK (1998) Plant-microbe competition for soil amino acids in the alpine tundra: effects of freeze-thaw and dryrewet events. Oecologia 113:406-414

Malik A, Blagodatskaya E, Gleixner G (2013) Soil microbial carbon turnover decreases with increasing molecular size. Soil Biol Biochem 62:115-118

Männistö MK, Tiirola M, Häggblom MM (2009) Effect of freezethaw cycles on bacterial communities of Arctic tundra soil. Microb Ecol 58:621-631

Matzner E, Borken W (2008) Do freeze-thaw events enhance C and $\mathrm{N}$ losses from soils of different ecosystems? A review. Eur J Soil Sci 59:274-284

McMahon SK, Wallenstein MD, Schimel JP (2009) Microbial growth in Arctic tundra soil at $-2^{\circ} \mathrm{C}$. Environ Microbiol Rep 1:162-166

Miranda KM, Espey MG, Wink DA (2001) A rapid, simple spectrophotometric method for simultaneous detection of nitrate and nitrite. Nitric Oxide Biol Chem 5:62-71

Morgner E, Elberling B, Strebel D, Cooper EJ (2010) The importance of winter in annual ecosystem respiration in the High Arctic: effects of snow depth in two vegetation types. Polar Res 29:58-74

Morley CR, Trofymow JA, Coleman DC, Cambardella C (1983) Effects of freeze-thaw stress on bacterial-populations in soil microcosms. Microb Ecol 9:329-340

Mulvaney RL (1996) Nitrogen—inorganic forms. In: Sparkes DL (ed) Methods of soil analysis. Part 3. Chemical methods. Soil Science Society of America, Madison, pp 1123-1184

Oswald SA, Nisbet ICT, Chiaradia A, Arnold JM (2012) FlexParamCurve: $\mathrm{R}$ package for flexible fitting of nonlinear parametric curves. Methods Ecol Evol 3:1073-1077

Özgül M, Günes A, Esringü A, Turan M (2012) The effects of freezeand-thaw cycles on phosphorus availability in highland soils in Turkey. J Plant Nutr Soil Sci 175:827-839

Payne JW, Smith MW (1994) Peptide-transport by microorganisms. Adv Microb Physiol 36:1-80

Roberts P, Jones DL (2012) Microbial and plant uptake of free amino sugars in grassland soils. Soil Biol Biochem 49:139-149

Rousk J, Brookes PC, Glanville HC, Jones DL (2011) Lack of correlation between turnover of low-molecular-weight dissolved organic carbon and differences in microbial community composition or growth across a soil $\mathrm{pH}$ gradient. Appl Environ Microbiol 77:2791-2795

Schimel JP, Clein JS (1996) Microbial response to freeze-thaw cycles in tundra and taiga soils. Soil Biol Biochem 28:1061-1066

Semenchuk PR, Elberling B, Cooper EJ (2013) Snow cover and extreme winter warming events control flower abundance of some, but not all species in high Arctic Svalbard. Ecol Evol 3:2586-2599

Skogland T, Lomeland S, Goksoyr J (1988) Respiratory burst after freezing and thawing of soil-experiments with soil bacteria. Soil Biol Biochem 20:851-856

Stres B, Philippot L, Faganeli J, Tiedje JM (2010) Frequent freezethaw cycles yield diminished yet resistant and responsive microbial communities in two temperate soils: a laboratory experiment. FEMS Microbiol Ecol 74:323-335

Strickland MS, Callaham MA Jr, Davies CA, Lauber CL, Ramirez K, Richter DD, Fierer N, Bradford MA (2010) Rates of in situ carbon mineralization in relation to land-use, microbial community and edaphic characteristics. Soil Biol Biochem 42:260-269

Tierney GL, Fahey TJ, Groffman PM, Hardy JP, Fitzhugh RD, Driscoll CT (2001) Soil freezing alters fine root dynamics in a northern hardwood forest. Biogeochemistry 56:175-190

Van Hees PAW, Jones DL, Finlay R, Godbold DL, Lundstomd US (2005) The carbon we do not see-the impact of low molecular weight compounds on carbon dynamics and respiration in forest soils: a review. Soil Biol Biochem 37:1-13

Vance ED, Brookes PC, Jenkinson DS (1997) An extraction method for measuring soil microbial biomass-C. Soil Biol Biochem 19:703-707

Vestgarden LS, Austnes K (2009) Effects of freeze-thaw on C and N release from soils below different vegetation in a montane system: a laboratory experiment. Glob Change Biol 15:876-887

Wilson SL, Walker VK (2010) Selection of low-temperature resistance in bacteria and potential applications. Environ Technol 31:943-956

Yu X, Zou Y, Jiang M, Lu XG, Wang GP (2011) Response of soil constituents to freeze-thaw cycles in wetland soil solution. Soil Biol Biochem 43:1308-1320 